\title{
Healthy Life For Smart Community: Gerakan Bebas Kanker Dan Penyakit Tidak Menular
}

\author{
Nur Chayati ${ }^{i^{*}}$, Yuni Astuti ${ }^{1}$, dan Nur Azizah Indriastuti ${ }^{1}$ \\ 1,2,3. Prodi IImu Keperawatan, Fakultas Kedokteran dan IImu Kesehatan,Universitas Muhammadiyah Yogyakarta, Jalan \\ Brawijaya, Tamantirto, Kasihan, Bantul, Yogyakarta \\ *Korespondensi: Nur Chayati, Ngrame, Tamantirto, Kasihan, Bantul, Yogyakarta, 55183, Telepon 6285794226267 \\ Email: nchayati1983@gmail.com \\ DOI: 10.18196/ppm.39.118
}

\begin{abstract}
Abstrak
Jumlah penduduk wanita di Dukuh Banyusri yang lebih banyak dibanding laki-laki menjadi kewaspadaan dalam bidang kesehatan. Meningkatnya prevalensi penyakit tidak menular yang menjadi penyebab kematian tertinggi, yaitu kanker payudara dan kanker cerviks pada wanita serta kanker prostat dan scrotum pada laki-laki perlu menjadi perhatian. Tujuan dari abdimas ini, yaitu melakukan screening status kesehatan umum dan pendidikan kesehatan tentang kanker di Dukuh Banyusri, Jatinom, Klaten. Metode kegiatan dimulai dengan pemeriksaan general check up, kemudian pretest, dilanjutkan pemberian pendidikan kesehatan tentang kanker payudara dan prostat, serta memberikan pelatihan SADARI (pemeriksaan payudara sendiri) dan SABURI (pemeriksaan burung sendiri). Kegiatan diakhiri dengan posttest. Hasil kegiatan diperoleh data jumlah warga yang terlibat sejumlah 42 warga (24 perempuan, 18 laki-laki), insiden buta warna sebanyak 43\%, tekanan darah sistole tertinggi $248 \mathrm{mmHg}$, tekanan darah diastole tertinggi $147 \mathrm{mmHg}$ (21 warga berstatus hipertensi dan hipertensi emergensi). Terdapat peningkatan pengetahuan sebesar $80 \%$ tentang kanker pada warga laki-laki dan peningkatan pengetahuan sebanyak $60 \%$ pada perempuan sebelum dan setelah pendidikan kesehatan. Dapat disimpulkan bahwa kegiatan abdimas mampu meningkatkan pengetahuan warga tentang kanker sekaligus terdeteksi bahwa warga Dukuh Banyusri memiliki pravelensi buta warna yang tinggi, serta berisiko tinggi terhadap penyakit tidak menular yaitu hipertensi. Diperlukan upaya lanjutan untuk meningkatkan status kesehatan warga dan pencegahan terjadinya komplikasi akibat hipertensi.
\end{abstract}

Kata Kunci: healthy life, smart community, kanker, penyakit tidak menular

\section{Pendahuluan}

Dukuh Banyusri merupakan salah satu dukuh yang terletak di Kecamatan Jatinom, Kabupaten Klaten, Jawa Tengah. Daerah Kabupaten Klaten terbentang di antara Daerah Istimewa Yogyakarta dan Kota Surakarta yang dilewati Jalan Raya Yogya-Solo yang mempunyai peranan sangat penting dalam memperlancar segala kegiatan ekonomi. Jarak Kabupaten Klaten dengan Daerah Istimewa Yogyakarta sekitar $40 \mathrm{~km}$ yang dapat ditempuh selama 2 jam menggunakan kendaraan bermotor. Kabupaten Klaten membawahi banyak kecamatan, salah satunya adalah Kecamatan Jatinom. Kecamatan Jatinom berada di wilayah utara tepatnya di dataran lereng Gunung Merapi. Kecamatan Jatinom memiliki 18 desa yang tersebar merata di seluruh wilayah kecamatan. Dengan banyaknya jumlah penduduk di Kecamatan Jatinom, atas peraturan pemerintah, kecamatan Jatinom di pecah menjadi beberapa desa dan satu desa membawahi beberapa dukuh. Salah satu desa yang berada di bagian paling barat Kecamatan Jatinom adalah Desa Krajan yang membawahi beberapa dukuh, diantaranya adalah Dukuh Banyusri.

Dukuh Banyusri terletak di dataran tinggi yang terbagi menjadi empat Rukun Tetangga, yaitu RT 8, 9, 10 dan 11. Jumlah anak usia sekolah di dukuh Banyusri hampir mencapai 30\% dari total jumlah keseluruhan penduduk. Anak-anak ini sebenarnya berminat untuk ikut TPA (Taman Pendidikan Al-Qur'an), tetapi karena letak TPA yang jauh, berada di dukuh sebelah, sebagian besar anak-anak ini lebih memilih menghabiskan waktu sepulang sekolah dengan bermain. Data dari Ikatan Remaja Masjid Dukuh Banyusri juga menyatakan bahwa masih ada sekitar $30 \%$ penduduk yang buta huruf Al-Qur'an. Dua permasalahan tersebut akhirnya menggerakkan remaja masjid untuk membentuk rumah tahfidz. Rumah tahfidz ini diberi nama Al-Mustaqim Banyusri (RTAB) dengan markas di Masjid Al-Mustaqim Banyusri. Rumah 
tahfidz ini sebagai sarana media dakwah bagi masyarakat yang jarang tersentuh oleh ilmu agama.

Program kerja utama Rumah Tahfidz Al-Mustaqim Banyusri (RTAB) awalnya adalah memberantas buta huruf kuhusnya Al-Qur'an. Namun, dalam perkembangannya, RTAB juga mengambil peran sebagai penggerak beberapa kegiatan kemanusiaan lain, seperti bidang kesehatan dan kegiatan sosial lain untuk meningkatkan peran aktif masyarakat. Kegiatan yang pernah dilakukan, antara lain program bank sampah dan pemeriksaan kesehatan rutin setiap 3 bulan. Hal ini dilakukan karena di Dukuh Banyusri jarang dilakukan pendidikan kesehatan, selain posyandu balita. Dukuh Banyusri sebenarnya dekat dengan Puskesmas dan juga RS Muhammadiyah, tetapi jarang sekali petugas kesehatan yang terjun langsung memberikan edukasi kesehatan kepada masyarakat.

Beberapa permasalahan yang dikeluhkan warga di desa ini, yaitu banyaknya kasus kanker yang tidak memandang usia, baik pada laki-laki maupun perempuan. Selain itu, warga juga menyatakan sangat jarang sekali memeriksakan kondisi kesehatannya secara rutin di Puskesmas. Warga hanya akan datang periksa ketika keluhan sudah parah dan tidak mempan diobati dengan obat warung. Dari hasil survei awal, diketahui beberapa warga juga sering mengalami tekanan darah tinggi dengan keluhan pusing, tengkuk nyeri. Namun, mereka tidak mau berobat ke pelayanan kesehatan. Beberapa permasalah kesehatan ini jika diabaikan akan berdampak pada ekonomi dan produktivitas warga. Warga menyatakan bahwa belum pernah diadakan kegiatan tentang edukasi kesehatan, khususnya terkait kanker dan penyakit tidak menular. Dengan demikin, tujuan dari pengabdian masyarakat ini adalah untuk mendeteksi faktor risiko penyakit tidak menular pada warga melalui general check up serta meningkatkan pengetahuan warga tentang kanker, baik pada wanita maupun laki-laki.

\section{Metode Pelaksanaan}

Berdasarkan permasalahan yang ditemui, metode pelaksanaan kegiatan yang direncanakan sebagai berikut.

A. Jenis kegiatan yang dilakukan meliputi pemeriksaaan kondisi umum kesehatan/general check up, pemberian pendidikan kesehatan, dan praktik. Penjelasan lebih rinci dari masing-masing kegiatan dan data yang diperoleh dari setiap kegiatan dipaparkan sebagai berikut.

\section{General Check Up}

Kegiatan general check up yang dilakukan berupa pemeriksaan kesehatan secara umum, yaitu tekanan darah, berat badan, tinggi badan, dan screening buta warna. Screening buta warna menggunakan kartu Ishihara. Semua data hasil pemeriksaan tersebut dicatat dalam rekam medis khusus untuk kegiatan abdimas.

2. Pendidikan Kesehatan tentang Kanker dan Praktik Pemeriksaan SADARI dan SABURI

Pengabdi memberikan soal pretest terlebih dahulu sebelum pemberian pendidikan kesehatan. Setelah semua peserta mengisi soal pretest, dilanjutkan dengan pemberian materi tentang kanker terlebih dahulu yang dibagi dalam dua tempat berbeda dan pemberi materi yang berbeda pula. Dilanjutkan dengan simulasi dengan phantom, kemudian dilakukan praktik SADARI dan SABURI bersama-sama. Pemeriksaan SADARI ini dilakukan kepada ibu-ibu Dukuh Banyusri sementara SABURI ditujukan untuk bapakbapak. Pada akhir kegiatan dilakukan posttest untuk mengetahui pemahaman dan keterserapan materi yang sudah disampaikan. Data yang didokumentasikan adalah nilai pretest dan posttest. Untuk memperjelas tahap pelaksanaan kegiatan, ditampilkan dalam Gambar 1. sebagai berikut. 


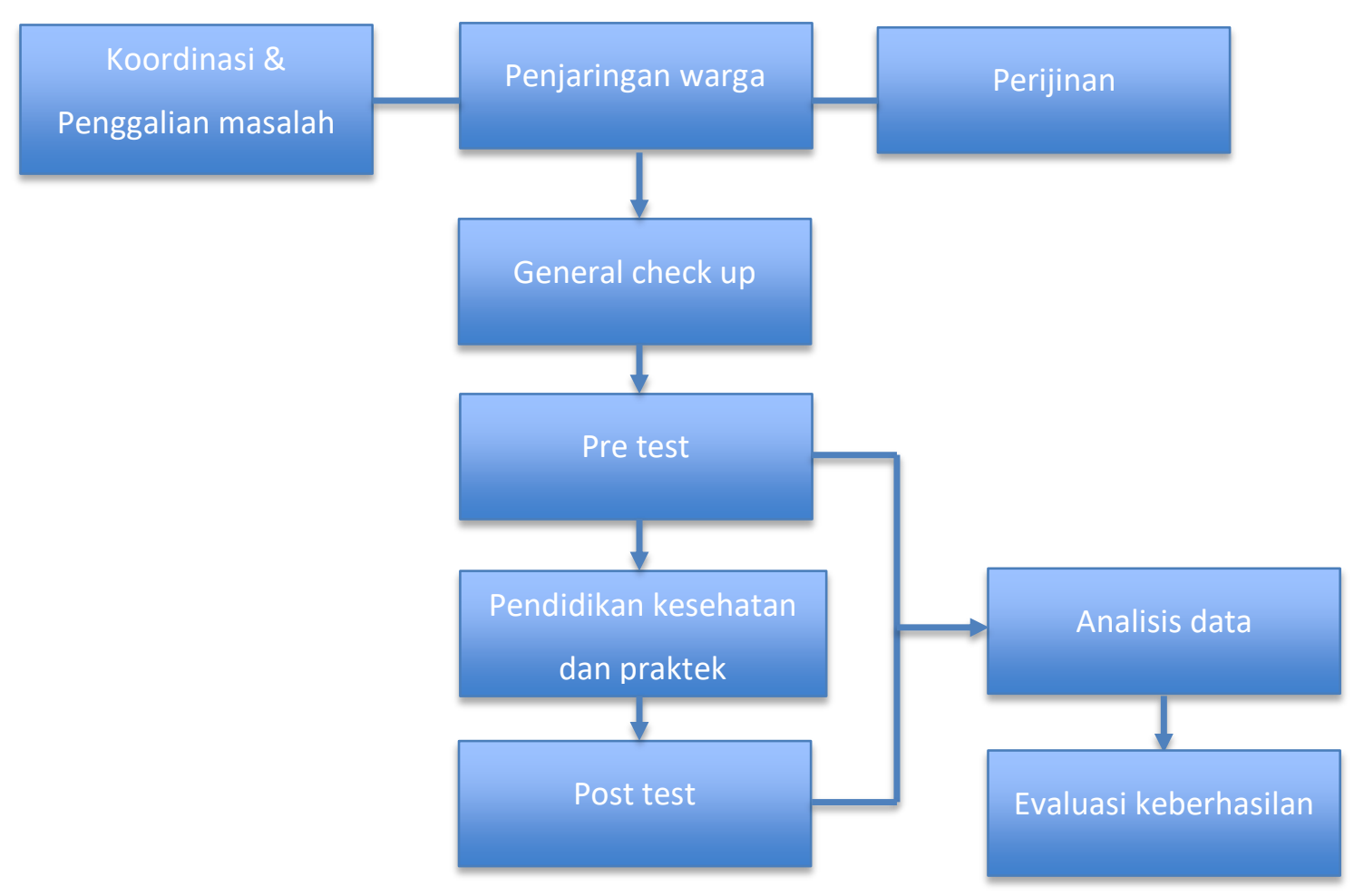

Gambar 1. Bagan Urutan Kegiatan Abdimas

\section{B. Lokasi Kegiatan}

Kegiatan pengabdian masyarakat dilaksanakan di rumah Bapak Sunardi RT 11, Dukuh Banyusri, Kecamatan Jatinom, Kabupaten Klaten, Jawa Tengah.

C. Khalayak Sasaran

Penjaringan warga dilakukan melalui media sosial lewat ketua RT masing-masing dan pengumuman di masjid. Peralatan yang dibutukan, yaitu tensi meter, stetoskop, timbangan berat badan, kartu Ishihara, phantom payudara dan alat kelamin laki-laki. Bentuk evaluasi terhadap keberhasilan program pengabdian adalah melakukan pretest dan posttest untuk mengetahui ada tidaknya peningkatan pengetahuan warga. Analisis data dilakukan menggunakan microsoft Excel.

D. Evaluasi Keberhasilan Kegiatan

Kegiatan abdimas ini dikatakan berhasil ketika kegiatan diikuti minimal 30 peserta dan terjadi peningkatan persentase pengetahuan warga dengan kategori baik pada posttest dibanding pretest.

\section{Hasil dan Pembahasan}

Kegiatan pengabdian masyarakat diikuti oleh 42 warga yang terdiri atas warga laki-laki 18 orang dan perempuan 24 orang. Distribusi jenis kelamin warga ditampilkan pada Gambar 2. Karakteristik kondisi kesehatan warga secara umum dipaparkan pada Tabel 1. 


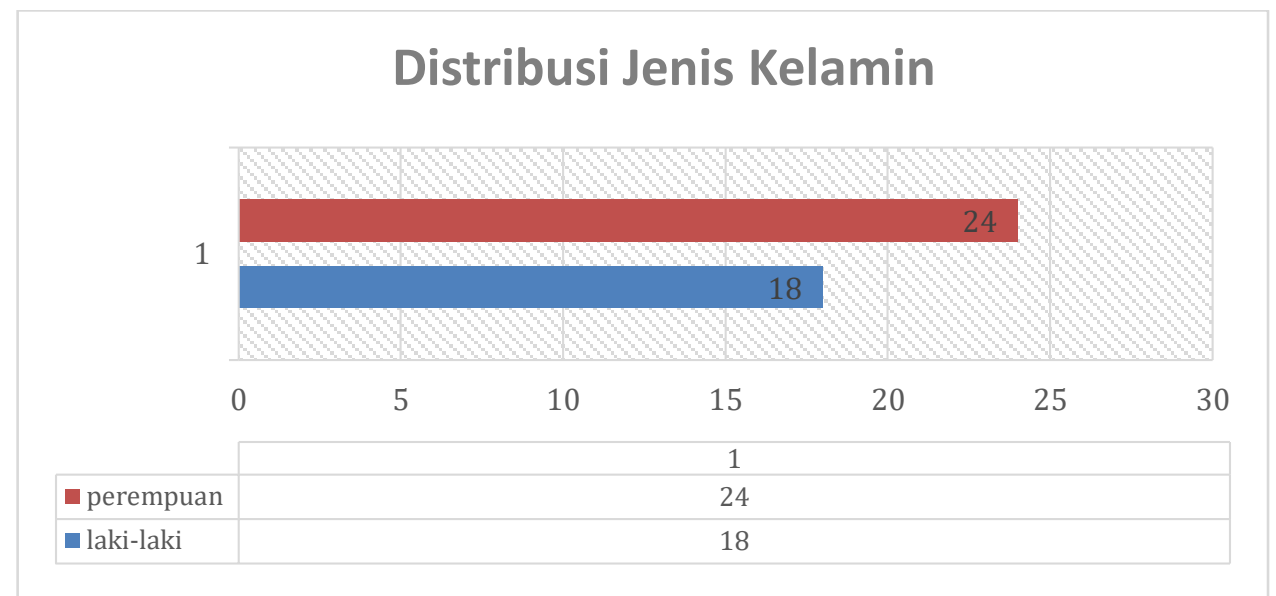

Gambar 2. Perbandingan Jumlah Warga Dewasa Perempuan dan Laki-laki pada Kegiatan Abdimas "Healthy Life for Smart Community" di Dukuh Banyusri, 8 Maret 2020

Untuk gambaran kondisi kesehatan warga, diperoleh data bahwa kejadian buta warna pada warga sebanyak 43\% (Gambar 3). Hal ini menunjukkan bahwa prevelensi buta warna warga Banyusri cukup tinggi. Sejalan dengan penelitian (Purwoko, 2018) prevalensi penderita buta warna di Indonesia $0,7 \%$ berdasarkan pada keluhan yang sering dilaporkan oleh pasien. Riskesdas 2007 dalam (Fatoni, Prihatningtias, \& Saubig, 2019) melaporkan 7,4\% penduduk Indonesia menderita buta warna. Buta warna sebagian besar terjadi pada laki-laki $9 \%$ dan sedikit kasus pada perempuan 0,5\% (Anwar \& Hutagalung, 2018).

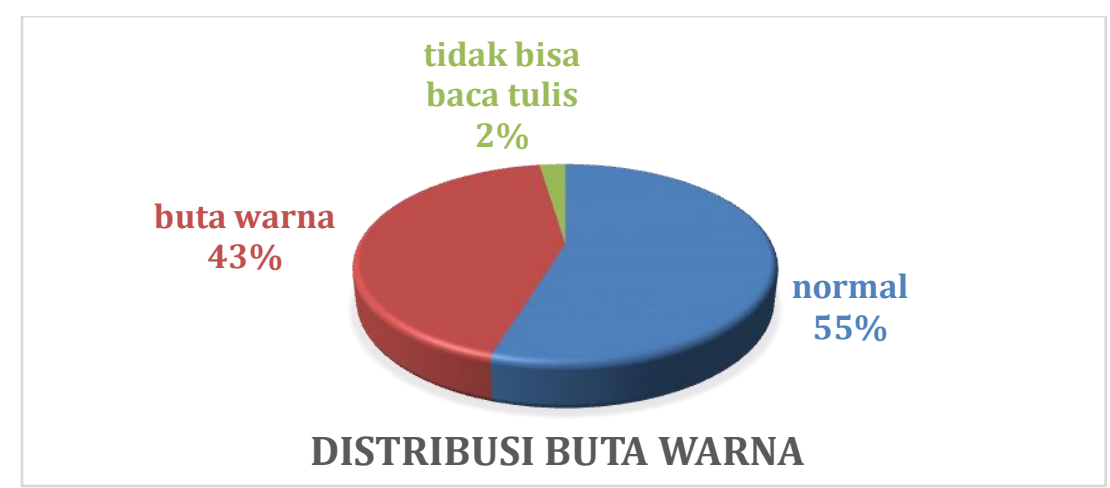

Gambar 3. Kejadian Buta Warna pada Warga pada Kegiatan Abdimas "Healthy Life for Smart Community" di Dukuh Banyusri, 8 Maret 2020

Tabel 1. Karakteristik Hasil General Check Up Warga pada Kegiatan Abdimas "Healthy Life for Smart Community" di Dukuh Banyusri, 8 Maret 2020 ( $n=42)$

\begin{tabular}{lccc}
\hline \multicolumn{1}{c}{ Karakteristik } & Rata-rata & Min-Mak & Standar Deviasi \\
\hline Usia & 61,3 & $35-86$ & 13,3 \\
\hline TD Sistole & 150,8 & $105-248$ & 36,5 \\
\hline TD Diastole & 87,3 & $53-147$ & 17,3 \\
\hline BB & 56,8 & $32-82,7$ & 11,4 \\
\hline TB & 152,8 & $132,5-169$ & 7,3 \\
\hline
\end{tabular}

Dari tabel 1 terlihat bahwa usia paling muda warga yang ikut kegiatan pengabdian masyarakat adalah 35 tahun dan yang paling tua 86 tahun. Tekanan darah sistole paling tinggi mencapai $248 \mathrm{mmHg}$, sementara tekanan darah diastole tertinggi hingga $147 \mathrm{mmHg}$. Berat badan paling kurus $32 \mathrm{~kg}$ dan yang paling gemuk 82,7 kg. Tekanan sistol dan diastole yang tinggi pada hasil general check up warga mengindikasikan kemungkinan hipertensi pada warga. Hipertensi merupakan peningkatan tekanan darah arteri yaitu sistol $>/=140 \mathrm{mmHg}$ dan diastole >/= $90 \mathrm{mmHg}$ dan merupakan penyebab kematian yang jarang disadari oleh penderita hingga 
menimbulkan komplikasi kesehatan (Oktaviarini, Chasani, Suwondo, \& Setyawan, 2019). Berdasarkan Riskesdas tahun 2007 dan 2013 dalam (Fatimah, et al., 2017) terdapat peningkatan prevalensi penderita hipertensi di Indonesia dari 29,8\% menjadi 31,7\% dan obesitas merupakan salah satu faktor risiko yang menyebabkan naiknya angka hipertensi tersebut. Hipertensi merupakan penyakit tidak menular yang dapat mengganggu taraf hidup kesehatan masyarakat terutama warga Banyusri sehingga selanjutnya perlu dilakukan pendidikan kesehatan terkait hipertensi guna mencegah kejadian dan perburukan penyakit hipertensi. Sejalan dengan penelitian (Rahayu, Usman, Nirwana, \& Firnawati, 2018) pengetahuan sangat memengaruhi perilaku seseorang dalam mencegah terjadinya penyakit hipertensi, pengetahuan yang kurang dapat menyebabkan perilaku hidup yang tidak baik dan meningkatkan risiko terjadinya hipertensi.

Hasil wawancara sebelum dilakukan penyuluhan semua peserta menyampaikan belum pernah melakukan pemeriksaan kanker dan tidak mengetahui bagaimana pemeriksaan untuk mendeteksi kanker. Setelah mendapatkan penyuluhan didapatkan peningkatan pengetahuan ibuibu tentang pencegahan kanker pada perempuan.

Tabel 2. Level Pengetahuan Warga Perempuan tentang Kanker Sebelum dan Setelah Pendidikan Kesehatan pada Kegiatan Abdimas "Healthy Life for Smart Community" di Dukuh Banyusri, 8 Maret 2020 ( $n=24)$

\begin{tabular}{lcccc}
\hline Variabel & \multicolumn{2}{c}{ Pretest } & Posttest \\
\hline Pengetahuan & Jumlah (n) & Frekuensi (\%) & Jumlah (n) & Frekuensi (\%) \\
Baik & 0 & 0 & 12 & 50 \\
Cukup & 12 & 50 & 6 & 25 \\
Kurang & 12 & 50 & 6 & 25 \\
Jumlah & 24 & 100 & 24 & 100 \\
\hline
\end{tabular}

Hasil tabel 2 menunjukkan bahwa pengetahuan setengah peserta memiliki tingkat pengetahuan yang baik $12(50 \%)$ setelah mendapatkan penyuluhan. Hasil ini sesuai dengan penelitian Wang, et al. (2012) yang menunjukkan terdapat perbedaan pengatahuan setelah mendapatkan edukasi tentang pencegahan kanker, terdapat perbedaan rata-rata tingkat pengetahuan pada responden yang mendapatkan edukasi dan yang tidak mendapatkan edukasi. Perempuan yang memiliki pengetahuan tinggi mampu memiliki self-efficacy yang tinggi tentang kanker dan deteksi dini (Ebu, et al., 2019). Perempuan yang memiliki pengetahuan baik mampu memiliki perilaku yang baik dalam melakukan deteksi dini kanker. Hal ini membuktikan bahwa pemberian edukasi mampu meningkatkan kemampuan. Seperti yang disampaikan Yilmaz et al. (2017) bahwa pemberian edukasi mampu meningkatkan pengetahuan dan perilaku dalam melakukan deteksi dini.

Hasil observasi setelah dilakukan penyuluhan seluruh peserta mampu mempraktikkan kembali pemeriksaan SADARI. Peningkatan kemampuan dalam melakukan deteksi dini mampu meningkatkan prognosis dari kejadian kanker payudara. Pemeriksaan SADARI ini mampu mengetahui secara dini perubahan yang ada pada payudara. SADARI yang dilakukan secara rutin mampu mendeteksi perubahan yang terjadi pada payudara. Perempuan yang tidak melakukan pemeriksaan SADARI secara rutin beresiko 1,348 kali memiliki ukuran tumor yang lebih besar (Thaineua, et al., 2019). Perempuan harus mengetahui kondisi normal dan perubahan yang terjadi pada payudara dan melaporkan pada tenaga kesehatan apabila terdapat perubahan pada payudara (American Cancer Society, 2020). 


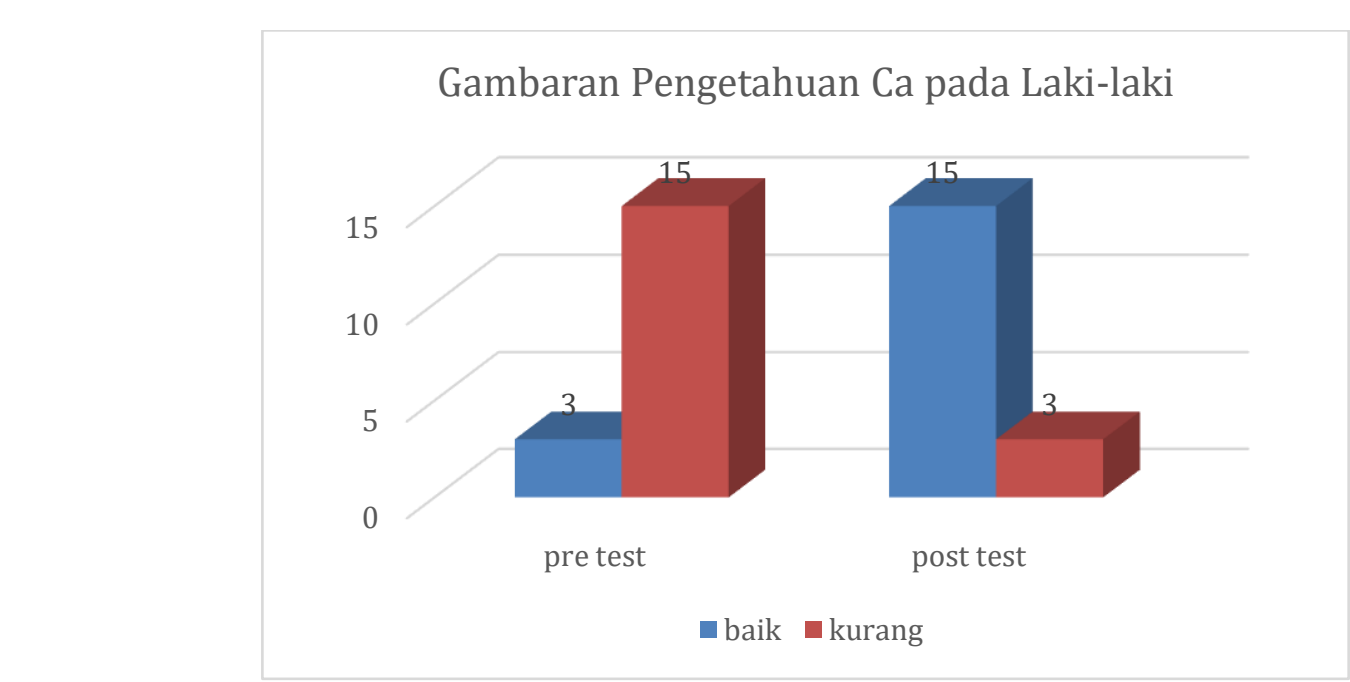

Gambar 3. Kemampuan Mitra Mengetahui tentang Organ Reproduksi Laki-laki dan Keganasan pada Organ Reproduksi Laki-laki pada Kegiatan Abdimas "Healthy Life for Smart Community" di Dukuh Banyusri, 8 Maret 2020 (N=18)

Gambar 3 menunjukkan bahwa sebelum pemberian materi (pretest), sebagian besar mitra (80\%) belum tahu tentang organ reproduksi pada pria dan keganasan pada organ reproduksi pria. Namun, setelah pemberian materi (posttest), jumlah mitra yang tahu tentang organ reproduksi pada pria dan keganasan pada organ reproduksi pria meningkat menjadi $80 \%$. Ini mengindikasikan terdapat peningkatan pengetahuan setelah diberikan pendidikan kesehatan tentang organ reproduksi pada pria dengan metode ceramah dan demonstrasi menggunakan phantom. Sejalan dengan hal ini, penelitian (Idris, Meo, \& Letor, 2018) menyatakan pendidikan kesehatan menggunakan metode ceramah dan demostrasi dengan alat peraga memungkinkan responden untuk lebih mudah memahami materi yang diberikan. Responden juga dapat mengetahui lokasi yang tepat serta istilah-istilah yang diberikan selama pendidikan kesehatan dengan cara melihat alat peraga demontrasi dan mendengarkan penjelasnnya. Dalam hal ini, informasi yang diberikan ditangkap melalui visual dan audio. Setelah dilakukan pendidikan kesehatan terkait organ reproduksi serta keganasan pada organ reproduksi pria, warga Banyusri diharapkan dapat mengaplikasikan materi yang diberikan untuk memelihara kesehatan reproduksi. Faktor penentu dalam memelihara kesehatan reproduksi salah satunya didasarkan pada pengetahuan yang dapat memperkuat terjadinya perubahan sikap untuk melakukan perawatan yang baik guna mencapai kesehatan reproduksi (Badriah, Wahyuni, \& Zaitun, 2015).

\section{Simpulan}

1. Terselenggara screening penyakit tidak menular yang dihadiri 42 warga (18 laki-laki, 24 perempuan), dengan hasil rata-rata berat badan $56,8 \mathrm{~kg}$; rata-rata tinggi badan $152,8 \mathrm{~cm} ; 21$ warga dalam status hipertensi dan hipertensi emergensi, $43 \%$ warga mengalami buta warna.

2. Terdapat peningkatan pengetahuan sebesar $80 \%$ tentang kanker pada warga laki-laki dan peningkatan pengetahuan sebanyak $60 \%$ pada warga perempuan sebelum dan setelah pemberian pendidikan kesehatan tentang kanker.

\section{Ucapan Terima Kasih}

Ucapan terima kasih kami tujukan kepada LP3M UMY sebagai pemberi dana utama kegiatan pengabdian masyarakat dengan nomor kontrak 031/PEN-LP3M/I/2020, warga Dukuh Banyusri yang turut aktif dalam kegiatan ini, serta mitra kegiatan yaitu RTAB atas dukungan fisik mamupun nonfisik sehingga kegiatan ini berjalan lancar. 
Daftar Pustaka

Ain, Q.U., Dar, N.Z., Ahmad, A., Munzar, S., Yousafzai, A.W. Caregiver Stress in Stroke Survivor: Data from A Tertiary Care Hospital-A Cross Sectional Survey. BMC Psychol. 2014;2(49):1-7.

American Cancer Society. (2020). American Cancer Society Recommendations for the Early Detection of Breast Cancer. https://www.cancer.org/cancer/breast-cancer/screeningtests-and-early-detection/american-cancer-society-recommendations-for-the-earlydetection-of-breast-cancer.html.

Anwar, K., \& Hutagalung, G. A. (2018). Analisis Penyakit Buta Warna dengan Perancangan Sistem Tes dengan Objek Citra. Seminar Nasional Rolay (p. 242). Asahan: STMIK Royal-Amik Royal.

Badriah, Wahyuni, S., \& Zaitun. (2015). Hubungan Pengetahuan dan Sikap terhadap Kesehatan Reproduksi Remaja di SMK Mandiri Cirebon. The Soedirman Journal of Nursing, Vol. 10, No. 1, 25-31.

Ebu, N.I., Amissah-Essel, S., Asiedu, C., Akaba, S., Pereko, K.A. (2019). Impact of health education intervention of cervical cancer and screening for women in Ghana. BMC Public Health. 19:1505. https://doi.org/10.1186/s12889-019-7867-x.

Fatimah, S.N., Akbar, L.B., Purba, A., Nugraha, G.I., Radhiyanti, P.T., \& Nurhayati, T. (2017). Hubungan Pengukuran Lemak Subkutan dengan Indeks Massa Tubuh pada Laki-laki Usia Lanjut. Jurnal Penelitian Gizi Dan Makanan, Vol. 40, No. 1, 30.

Fatoni, M.R., Prihatningtias, R., \& Saubig, A.N. (2019). Hubungan Jumlah Konsumsi Rokok Per Hari pada Perokok Aktif dengan Gangguan Penglihatan Warna. Jurnal Kedokteran Diponegoro, Vol. 8, No. 2, 871.

Idris, R.A., Meo, M.L., \& Letor, Y.M. (2018). Pengaruh Metode Ceramah dan Demonstrasi terhadap Pengetahuan dan Keterampilan Wanita Usia Subur (WUS) Melakukan Pemeriksaan Payudara Sendiri (SADARI) di Puskesmas Bakuna Se-Kota Kupang. CHMK Nursing Scientific Journal, Vol. 2, No. 1, 30-31.

Oktaviarini, E., Chasani, S., Suwondo, A., \& Setyawan, H. (2019). Faktor yang Berisiko terhadap Hipertensi pada Pegawai di Wilayah Perimeter Pelabuhan (Studi di Kantor Kesehatan Pelabuhan Kelas II Semarang). Jurnal Epidemiologi Kesehatan Komunitas, Vol. 4, No. 1, 36.

Purwoko, M. (2018). Prevalensi Buta Warna Pada Mahasiswa Universitas Muhammadiyah Palembang. Jurnal Kedokteran Brawijaya, Vol 30, No. 2, 160.

Rahayu, D.Y., Usman, R.D., Nirwana, \& Firnawati. (2018). Pengaruh Health Education Mengenai Penyakit Hipertensi pada Lansia yang Tinggal di Panti Jompo. Jurnal Penelitian Health Information, Vol. 10, No. 2, 50.

Thaineua, V., Ansusinha, T., Auamkul, N., Taneepanichskul, S., Urairoekkun, C., Jongvanich, J., Kannawat, C., Traisathit, P., Chitapanarux, I. (2019). Impact of Regular Breast SelfExamination on Breast Cancer Size, Stage, dan Mortality in Thailand. The Breast Journal, 26: 822-824. DOI: 10.1111/tbj.13611.

Wang, H., Chung, Y., Sun. J. (2012). The Effect of Education Program on Knowledge and Intention of Breast Cancer Screening in Taiwan. Asian Pacific Journal of Cancer Prevention. $13 \quad$ (11),

$5545-5549$.

DOI:http://dx.doi.org/10.7314/APJCP.2012.13.11.5545.

Yilmaz, M., Sayin, Y., Cengiz, H.O. (2017). The Effect of Training on Knowledge and Beliefs about Breast Cancer and Early Disgnosis Methods among Women. Euro Journal Breast Health, 13: 175-182. DOI: 10.5152/tjbh.2017.3255. 